\title{
MULTILEVEL ANALYSIS ON THE DETERMINANTS OF HEALTHY BEHAVIOR AMONG THE ELDERLY
}

\author{
Nurul Jannah'), Didik Tamtomo²), RB Soemanto3) \\ 1)Masters Program in Public Health, Universitas Sebelas Maret \\ 2)Faculty of Medicine, Universitas Sebelas Maret \\ 3)Faculty of Social and Political Sciences, Universitas Sebelas Maret
}

\begin{abstract}
Background: Health behavior and lifestyle are identified as the main factors affecting human health. Adverse health behavior and lifestyle affect all age groups (e.g., obesity in teenagers, heart disease in adults, cerebrovascular disease, malignant tumor, etc.), but its influence on the elderly is significant. Old people represent a population highly at risk for chronic diseases and fall injuries. The purpose of this study was to examine the determinants of healthy behavior among the elderly.

Subjects and Method: This was a cross-sectional study carried out in integrated health posts (posyandu) in Lamongan, East Java, from November to December 2018. A sample of 200 elderly was selected by stratified random sampling. The dependent variable was health behavior. The independent variables were education, intention, attitude, peer support, family support, cadre support, perceived behavior control, subjective norm, and posyandu strata. The data were collected by questionnaire and analyzed by a multilevel multiple linear regression.

Results: Health behavior among elderly was positively affected by education $(b=0.76 ; 95 \%$ $\mathrm{CI}=0.29$ to $1.23 ; \mathrm{p}=0.002)$, intention $(\mathrm{b}=0.08 ; 95 \% \mathrm{CI}=0.01$ to $0.15 ; \mathrm{p}=0.028)$, attitude $(\mathrm{b}=$ $0.20 ; 95 \% \mathrm{CI}=0.08$ to $0.32 ; \mathrm{p}=0.001)$, perceived behavior control $(\mathrm{b}=0.18 ; 95 \% \mathrm{CI}=0.07$ to $0.30 ; \mathrm{p}=0.002)$, subjective norm $(\mathrm{b}=0.10 ; 95 \% \mathrm{CI}=-0.01$ to $0.21 ; \mathrm{p}=0.057)$, peer support $(b=0.07 ; 95 \% \mathrm{CI}=-0.01$ to $0.15 ; \mathrm{p}=0.053)$, family support $(\mathrm{b}=0.19 ; 95 \% \mathrm{CI}=0.08$ to 0.30 ; $\mathrm{p}<0.001)$, and cadre support $(\mathrm{b}=0.13 ; 95 \% \mathrm{CI}=0.04$ to $0.23 ; \mathrm{p}=0.003)$. Integrated health post had negligible contextual effect on health behavior with ICC $<1 \%$.

Conclusion: Health behavior among elderly is positively affected by education, intention, attitude, perceived behavior control, subjective norm, peer support, family support, and cadre support. Integrated health post has negligible contextual effect on health behavior.
\end{abstract}

Keywords: health behavior, elderly, path analysis

Correspondence:

Nurul Jannah. Masters Program in Public Health, Universitas Sebelas Maret. Jl. Ir. Sutami 36A, Surakarta 57126, Central Java, Indonesia. Email: njannah.31@gmail.com.

Mobile: +6282230300405 .

The 5th International Conference on Public Health

Best Western Premier Hotel, Solo, Indonesia, February 13-14, 2019 | 169 https://doi.org/10.26911/theicph.2019.02.14 